Diabetologia 8, 202-205 (1972)

(C) by Springer-Verlag 1972

\title{
Abnormal Carbohydrate Metabolism in Patients with Liver Cirrhosis; in vitro Study
}

\author{
Viera Dzúrizová, T.R. Niederland, Eva Brixová, R. Dzứrtk, Viera Hupgová and J. Holomáy̆ \\ Laboratory of Experimental Therapy, III. Medical Clinic, Comenius University Medical School, Bratislava, \\ Czechoslovakia
}

Received: December 1, 1971, accepted: January 14, 1972

\begin{abstract}
Summary. The serum of patients with liver cirrhosis inhibits glucose utilization in rat diaphragm. Inhibition is not caused by increased glycogenolysis or decreased glycogen synthesis. Lactate production and fructose utilization are not changed, indicating that the inhibition of glucose utilization is localized at the level of transmembrane transport of glucose or at the level of hexose phosphates. The inhibitory activity of cirrhotic serum, fractioned by gel filtration moves with peptides and aminoacids, excluding the significance of FFA and of growth hormone.
\end{abstract}

Métabolisme anormal des hydrates de carbone chez des malades avec cirrhose du foie: étude in vitro

Résumé. Le sérum des malades avec cirrhose du foie empêche l'utilisation de glucose dans le diaphragme du rat. L'inhibition n'est pas provoquée par une augmentation de la glycogénolyse ou une réduction de la synthèse du glycogène. La production de lactate et 1'utilisation de fructose ne changent pas, ce qui signifie que l'inhibition de l'utilisation de glucose reste localisée au niveau du transport de glucose à travers la membrane ou bien au niveau de l'hexose phosphate. L'activité inhibitrice du sérum cirrhotique fractionné par filtration sur gel se déplace avec des peptides et des acides aminés, ce qui exclue le rôle des acides gras libres et de l'hormone de croissance.

Gestörter Kohlenhydratmetabolismus bei Patienten mit Leberzirrhose: Eine in-vitro Studie

Zusammenfassung. Serum von Patienten mit Leberzirrhose vermindert die Glucosutilisation am Diaphragma der Ratte. Diese Verminderung wird nicht durch eine erhöhte Glykogenolyse oder eine verminderte Glykogensynthese verursacht. Die Lactat- und Fructoseutilisation werden nicht verändert, was daraufhin deutet, daß die Verminderung der Glucoseutilisation auf dem Niveau des Membrantransportes der Glucose oder auf dem Niveau des Hexosephosphats liegen muß. Die Hermmaktivität des Cirrhoseserums wandert bei einer Sephadexgelchromatographie mit Peptiden und Aminosäuren, was einen Einfluß der freien Fettsäuren und des Wachstumshormons ausschließt.

Key words : Liver cirrhosis, carbohydrate metabolism, serum fractionation, glucose utilization in muscle, free fatty acids, peptides.
A great number of patients with liver diseases suffer from abnormal glucose tolerance $[4,14]$. Decreased glucose utilization at the periphery was demonstrated repeatedly $[3,8,4,1]$ and the participation of muscle in this decrease was shown by measuring glucose uptake in the forearm of the cirrhotic patients [9].

Several factors were proposed to decrease peripheral glucose uptake in patients with liver diseases: 1. Decreased glucose production in liver is counterbalanced by the decreased glucose uptake in muscle [1]. 2. Decreased utilization of various metabolites in liver causes their accumulation and preponderant utilization in muscle [9]. 3. Insulin resistance reflects in decreased glucose utilization in muscle. The resistance may be caused either by the lack of insulin synergists, such as potassium [13, 2], uridine and cytidine [7], or by the accumulation of insulin antagonists, such as free fatty acids $[8,13,10,11]$ and growth hormone $[16$, 13]. 4. Insulin may be more closely bound to plasma constituents leading to the loss in biologic activity [4].

It would be rather complicated to study the significance of these, as well as other factors participating in abnormal carbohydrate metabolism, in vitro. Therefore, an in vitro technique was elaborated, which enables comparison of glucose utilization by rat hemidiaphragm incubated in cirrhotic serum with that found in hemidiaphragm incubated in control serum. This technique enables us to study the effect of modulators present in serum and excludes the significance of intracellular factors. This technique was found to be fruitful in the study of abnormal carbohydrate metabolism in uraemia $[5,6]$.

\section{Material and Methods}

Study was performed with blood samples obtained from eight patients with liver cirrhosis, established by laparoscopy and liver biopsy. Their pertinent laboratory data are given in Table 1 . All but one had abnormal glucose tolerance tests, none of them was diabetic. Control blood samples were obtained from normal volunteers, with normal physical and laboratory findings.

Blood samples were collected in the morning after an overnight fast and allowed to stand for $30 \mathrm{~min}$ at room temperature before centrifugation. The separated serum was diluted with an equal volume of Ringer bicarbonate, containing $5 \mathrm{mM}$ glucose. Diluted sera were used for incubation as media. 
Table 1. Clinical diagnosis and pertinent laboratory data of patients at the time of the study

\begin{tabular}{|c|c|c|c|c|c|c|c|c|c|}
\hline $\begin{array}{l}\text { Patient } \\
\text { No. }\end{array}$ & age & sex & diagnosis & $\begin{array}{l}\text { serum } \\
\text { albumin } \\
\mathrm{g} / 100 \mathrm{ml}\end{array}$ & $\begin{array}{l}\text { potassium } \\
\mathrm{mE} / 1\end{array}$ & $\begin{array}{l}\text { alkali } \\
\text { reserve }\end{array}$ & $\begin{array}{l}\text { BSP } \\
\text { retention } \\
45 \text { min }\end{array}$ & $\begin{array}{l}\text { glucose } \\
\text { tolerance } \\
\text { test }\end{array}$ & $\begin{array}{l}\text { blood } \\
\text { ammonia } \\
\mu \mathrm{g} / 100 \mathrm{mal}\end{array}$ \\
\hline 1 & 67 & $\mathrm{~m}$ & $\begin{array}{l}\text { cryptogenic } \\
\text { cirrhosis } \\
\text { splenorenal } \\
\text { shunt-PSE }\end{array}$ & 2.5 & 5.0 & 18.0 & 70.0 & abnormal & 200.0 \\
\hline 2 & 40 & $\mathrm{~m}$ & $\begin{array}{l}\text { postnecrotic } \\
\text { cirrhosis } \\
\text { portal hyper- } \\
\text { tension, splenec- } \\
\text { tomy-PSE }\end{array}$ & 3.5 & 4.2 & 18.0 & 36.6 & abnormal & 170.0 \\
\hline 3 & 48 & $\mathrm{~m}$ & $\begin{array}{l}\text { cryptogenic } \\
\text { cirrhosis portal } \\
\text { hypertension }\end{array}$ & 2.8 & 4.4 & 18.0 & 7.0 & normal & 120.0 \\
\hline 4 & 48 & $\mathrm{~m}$ & $\begin{array}{l}\text { cryptogenic } \\
\text { cirrhosis portal } \\
\text { hypertension, } \\
\text { splenectomy }\end{array}$ & 3.1 & 3.9 & 22.0 & 18.3 & abnormal & 104.0 \\
\hline 5 & 57 & $\mathrm{~m}$ & $\begin{array}{l}\text { alcoholic } \\
\text { cirrhosis portal } \\
\text { hypertension }\end{array}$ & 3.2 & 3.5 & 22.0 & 24.1 & abnormal & 79.0 \\
\hline 6 & 51 & $\mathrm{f}$ & $\begin{array}{l}\text { postnecrotic } \\
\text { cirrhosis portal } \\
\text { hypertension, } \\
\text { uraemia }\end{array}$ & 3.3 & 3.4 & 14.0 & 18.8 & abnormal & \\
\hline 7 & 57 & $\mathrm{~m}$ & $\begin{array}{l}\text { alcoholic } \\
\text { cirrhosis }\end{array}$ & 3.1 & 3.7 & & 26.7 & abnormal & \\
\hline 8 & 53 & $\mathrm{~m}$ & $\begin{array}{l}\text { alcoholic } \\
\text { cirrhosis }\end{array}$ & 3.4 & 4.7 & 19.0 & 17.6 & abnormal & \\
\hline
\end{tabular}

Gel filtration: $1.5 \mathrm{ml}$ of serum was fractioned by gel filtration on a $35 \times 2 \mathrm{~cm}$ column packed with Sephadex G-25 (Pharmacia Fine Chemicals). The column was eluted with a solution of $0.03 \mathrm{M}$ ammonium acetate. $200 \mathrm{ml}$ of effluent solution was collected in $4.0 \mathrm{ml}$ fractions using an automatic fraction collector. On the basis of the absorption pattern at $280 \mathrm{~nm}$ the effluent solution was separated into four different fractions (Fig. 2). The fractions, resembling $10.5 \mathrm{ml}$ of serum were lyophilized. The lyophilized powder was dissolved in $21 \mathrm{ml}$ of Ringer bicarbonate containing $5 \mathrm{mM}$ glucose, which was used as medium for the incubation of rat hemidiaphragms.

Incubation: Diaphragms were obtained from male Wistar rats, $120-150 \mathrm{~g}$ weight, last fed $20 \mathrm{~h}$ before the experiment. Rats were decapitated, their diaphragms removed and immediately chilled in isotonic saline. Hemidiaphragms were incubated in cirrhotic or control sera alternatively at $37^{\circ} \mathrm{C}$ in a Dubnoff apparatus in an atmosphere of $95 \% 0_{2}-5 \% \mathrm{CO}_{2}$. After the incubation the diaphragms were removed and weighed. Glycogen concentration in diaphragm was determined by the anthrone method [14] after two precipitations with ethanol. Glucose and lactate were determined enzymatically by Boehringer commercial kits. Fructose was determined by the method of Kulka [12]. Analyses were performed in duplicate.

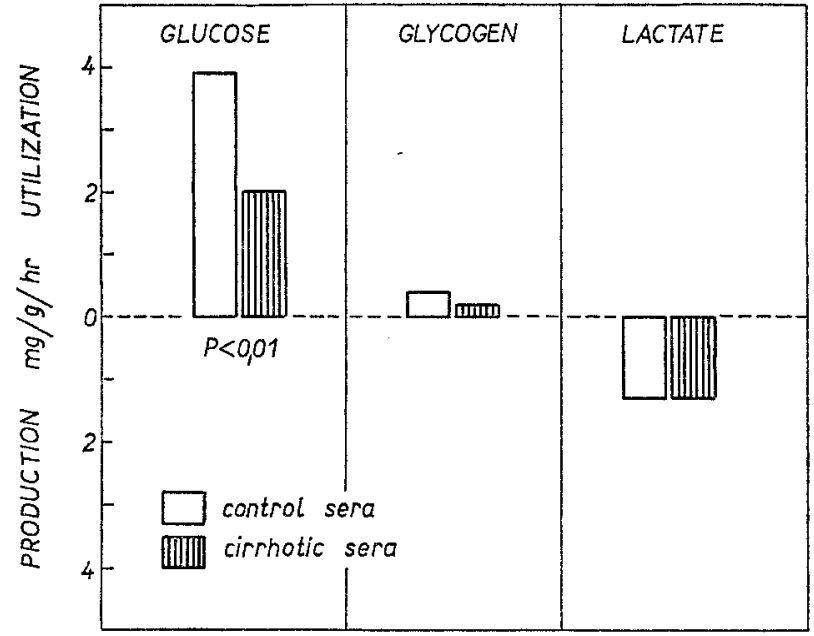

Fig. 1. The effect of cirrhotic sera on the utilization of glucose and glycogen and the production of lactate

\section{Results}

Rat hemidiaphragms incubated in sera obtained from cirrhotic patients utilized less glucose than those incubated in control sera (Fig. 1). One of the most important pathways interfering with glucose uptake is glycogenolysis and glycogen synthesis. In both con- 
trol and cirrhotic sera the diaphragms broke down glycogen (Fig. 1). But glycogenolysis represented only 10 percent of the amount of utilized glucose and was similar both in cirrhotic and control sera. Therefore, glycogenolysis did not explain the difference in glucose uptake.

A great part of the utilized glucose was metabolized to lactate. However, no significant difference was found in lactate synthesis in control and cirrhotic sera (Fig. 1). Therefore, it was proposed that the metabolic block is localized at the level of glycolysis. To prove this proposal and to localize the block more exactly,

Table 2. Fructose utilization by rat diaphragm incubated in cirrhotic and control sera. Sera were diluted with the same volume of Ringer bicarbonate with did not contain glucose, but its fructose concentration was $20 \mathrm{mM}$

\begin{tabular}{lc}
\hline Control sera & \multicolumn{1}{c}{ Cirrhotic sera } \\
\hline a $5.02 \pm 0.326(7)$ & $4.61 \pm 0.330(7)$ \\
\hline a arithmetic mean \pm S.E.M. & (number of sera)
\end{tabular}
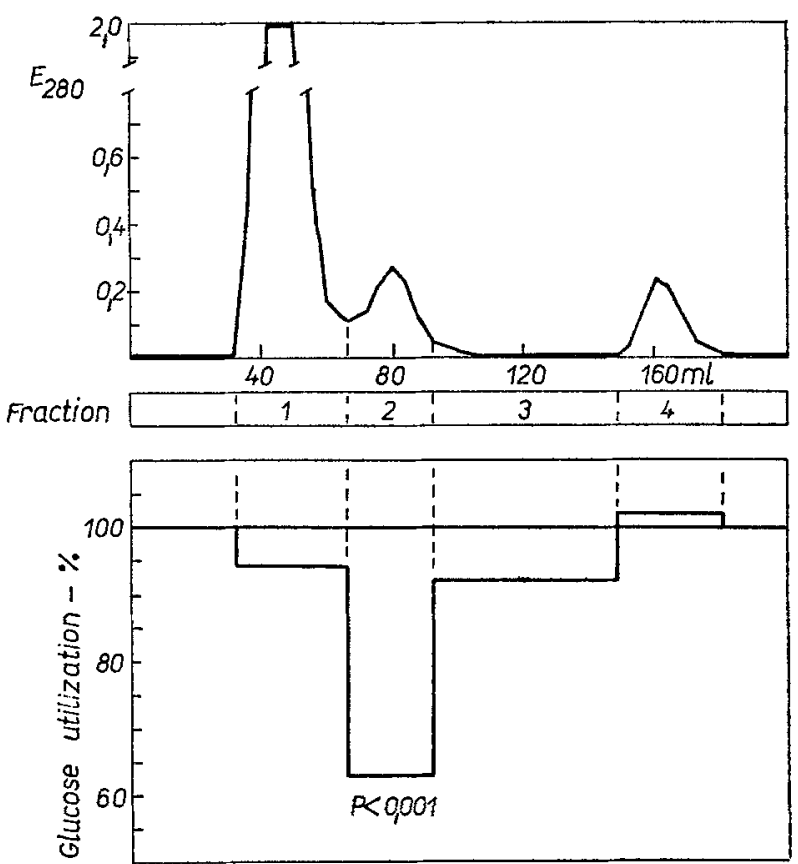

Fig. 2. Elution pattern of sera and the inhibitory activity of its fractions on the utilization of glucose. The results of glucose utilization are expressed in relative values, the control values being made 100 per cent

the utilization of fructose, which enters the glycolytic chain at the level of trioses, was measured. To exclude the significance of diffusion into the diaphragm, the concentration of fructose was increased to $20 \mathrm{mM}$. It was found (Table 2), that cirrhotic sera did not inhibit the utilization of fructose. On the basis of these results the block in glucose uptake can be localized at the level of transmembrane transport of glucose or at the level of hexose phosphates.

The exact site of the metabolic block was not studied further because of the complex nature of serum which was used for the incubation of hemidiaphragms. It was supposed that before any exact studies were to be performed, the inhibitor should be defined and eventually isolated and used in a pure state.

The feature of the inhibitor: Cirrhotic and control sera were fractioned by gel filtration on a column of Sephadex G25. After the fractionation four fractions were collected (Fig. 2):

Fraction 1, which contained proteins, as confirmed by the deproteinizing agents, staining with bromphenol blue and with the mobility of the purified albumin. It contained also free fatty acids, adsorbed to albumin or other proteins. This fraction prepared from the cirrhotic sera did not inhibit glucose utilization significantly when compared with the fraction 1, prepared from control sera.

Fraction 2 contained peptides and at the end of the peak also amino acids as confirmed by the ninhydrin staining and the mobility of Octapressine, Vasopressine (Sandoz), phenylalanine and glycine. The fraction prepared from the cirrhotic sera inhibited significantly glucose utilization when compared with the same fraction prepared from normal sera.

Fractions 3 and 4 containing undefined' substances had no significant effect on the glucose utilization.

\section{Discussion}

Two kinds of factors could participate to the inhibition of peripheral glucose utilization in liver diseases: 1. Intracellular factors, i.e. potassium depletion, intracellular acidosis etc. The significance of these factors was excluded in this study, because the hemidiaphragms were taken from normal rats and the hemidiaphragms were incubated alternatively in control and cirhotic sera. 2. Extracellular factors distributed in extracellular fluid and blood. These inhibitors were studied by this technique. On the basis of the presented results one can conclude that a factor is detectable in the serum of cirrhotic patients inhibiting glucose utilization.

The significance of FFA, which were suspected to be responsible for the decreased glucose utilization in liver diseases $[8,13,10,19]$ was excluded: They move with fraction 1 , while the inhibitory activity was restricted to fraction 2. Moreover, even the significance of growth hormone $[16,13]$ seems to be excluded: Its molecular weight determines its mobility in fraction 1. However, an effect produced by growth hormone fragments cannot be excluded.

On the basis of the fractionation study it can be concluded that the molecular weight of the inhibitor is less than 5000. However, the lower limit of the molecular weight cannot be proposed. The substances with 
molecular weight less than 1000 were not separated under the conditions used. We suggest, that the inhibitor is of peptide nature. It is suitable for isolation by ion-exchange chromatography or high-voltage electrophoresis. Of course, any further discussion on its nature and mode of action would be fruitless until it has been isolated.

Only patients with liver cirrhosis were included in this study. We would not like to suggest by this selection of patients, that special inhibitor is suspected in liver cirrhosis. It is probable, that the same inhibitor is present in patients with other liver diseases with abnormal glucose tolerance. However, it is possible, that other factors may interfere in different clinical entities. This was the reason for the selection of patients with liver cirrhosis.

\section{Literature}

1. Adlung, J., Ritter, U., Uthgenannt, H.: Untersuchungen über den Glucoseumsatz und die Glucoseoxidation bei der Leberzirrhose. Dtsch. med. Wschr. 95, $401-406$ (1970).

2. Conn, H.O.: Cirrhosis and Diabetes. IV. Effect of potassium chloride administration on glucose and insulin metabolism. Amer. J. med. Sci. 259, 394-404 (1970).

3. Creutzfeld, W., Wille, K., Kaup, H.: Intravenöse Belastungen mit Glucose, Insulin und Tolbutamid bei Gesunden, Diabetikern, Leberzirrhotikern und Insulomträgern. Dtsch. med. Wschr. 87, 2189-2195 (1962).

4. - Frerichs, H., Sickinger, K.: Liver diseases and diabetes mellitus. In: Progress in Liver Disease, vol. III, chapt. 23, 371. New York-London: Grune and Stratton 1970.

5. Dzúrik, R., Krajci-Lazáry, B.: The effect of uremic serum on carbohydrate metabolism in rat diaphragm. Experientia 23, 798-799 (1967).

6. - Valovicová, E.: Glucose utilization in muscle during uremia: in vitro study. Clin. chim. Acta 30, 137 $142(1970)$.

7. Elrick, H., Hlad, C.F., Arai, Y.: Influence of certain nucleosides on glucose utilization in man. Metabolism 11, 46-55 (1962).

8. Felber, J.P., Magnenat, P., Vannotti, A.: Tolérance au glucose diminuée et réponse insulinique élevée dans la cirrhose. Schweiz. med. Wschr. 97, 1537-1539 (1967).

9. Klassén, G.A., Aronoff, A., Karpati, G.: Forearm metabolism in patients with chronic liver disease. Clin. Sci. 37, 455-470 (1969).

10. Kopetz, K.: Zur Pathogenese des hepatogenen Diabetes Mellitus. Klin. Wschr. 48, 1259-1625 (1970).

11. - Wehrmann, P.: Stoffwechselveränderungen nach Glucose- und Tolbutamidbelastung bei Leberzirrhosen und ihre Rolle in der Pathogenese des hepatogenen Diabetes Mellitus. Klin. Wschr. 48, 1265-1276 (1970).

12. Kulka, R.G.: Colorimetric estimation of ketopentoses and ketohexoses. Biochem. J. 63, 542-548 (1956).

13. Magnenat, P.: Troubles de la régulation des hydrates de carbonne dans les lésions hépatiques. Helv. med. Acta 35, 354-362 (1969/70).

14. Megyesi, C., Samols, E., Marks, V.: Glucose tolerance and diabetes in chronic liver disease. Lancet 1967 II, $1051-1056$.

15. Morris, D.L.: Quantitative determination of carbohydrates with Dreywood's reagent. Science 107, 254255 (1948).

16. Samaan, N.A., Stone, D.B., Eckhardt, R.D.: Serum glucose, insulin and growth hormone in chronic hepatic cirrhosis. Arch. intern. Med. 124, 149-152 (1969).

Viera Dzúriková, M.D., Laboratory of Experimental Therapy, III. Medical Clinic,

Comenius University,

Medical School.

Bratislava-Kramáre, ČSSR 